ISSN : 2087-2461

PENANGGUNG JAWAB Dekan FIKOM

Evie Sofiati MI, M.I.Kom

Sekretaris Dekan

Dian Marhaeni K, M.Si

Ketua Penyunting

Made Dwi Adnjani, M.Si

Sekretaris

Mubarok, M.Si

Bendahara

Parwati, SH

Dewan Penyunting

Trimanah, M.Si

Edi Ismoyo, M.Si

Suharyoso, S.Sos

Seksi Usaha

Endang Winarsih, S.Sos

Sirkulasi dan Distribusi

Aldino Leoniv, ST

Alamat Redaksi

Fakultas Ilmu Komunikasi

Universitas Islam

Sultan Agung Semarang

J1. Raya Kaligawe Km. 4

Po. Box 1054/SM

Semarang 50112

Telp. (024) 6583584

ext. $448 / 449$

Fax. (024) 6582455

email : jurnalfikom@yahoo.com
Pengaruh Perubahan Nama Terhadap Citra Pada Telkom

University

Felesia Ekafaya Kirianawati, Roro Retno Wulan,

Kharisma Nasionalita

felesiaekafay@gmail.com

Komunikasi Lintas Budaya Etnis India, Etnis China serta

Pribumi di kampung Lubuk Pakam

Meilani Dhamayanti

mdhamayanti73@gmail.com

Analisis Komunikasi Pemasaran Melalui Strategi Brand Activation Pond's Untuk Meraih Top Brand Award 2013 Rustono Farady Marta ${ }^{1}$, Pricillia ${ }^{2}$, Maria Fransisca Kosasih ${ }^{3}$, Maria Christina Evelyn Iskandar ${ }^{4}$

rustonofarady@gmail.com ${ }^{1}$, icil_22@hotmail.com ${ }^{2}$, s43_s43@yahoo.com ${ }^{3}$,

mariachristinaevelyne@gmail.com ${ }^{4}$

Analisis Isi Visual Iklan Dan Strategi Kreatif Kategori Print Ad Pemenang Gold, Silver, dan Bronze Citra Pariwara 2015

Dina Nur Handayani ${ }^{1}$ (dinurhdyn@gmail.com)

Ratih Hasanah Sudrajat ${ }^{2}$ (kumaharatih@gmail.com ${ }^{2)}$

Ayub Ilfandy Imran ${ }^{3}$ (a_ilfandy@yahoo.com ${ }^{3}$ )

Refleksi Citra Indonesia Sebagai Dampak Politik Migrasi TKI

ke Malaysia

Mutia Rahmi Pratiwi (mutiarahmipratiwi@gmail.com)

Amida Yusriana (amidayusriana88@gmail.com)

$46-59$

Karakteristik Press Release Praktisi Public Relations Hotel di Yogyakarta

Margaretha Sonya, Meylani Yo, Nobertus Ribut Santoso

margaretha_sonyalee@yahoo.com

$60-70$

Isu LGBT dalam Bingkai Media Online

Muhammad Ghifari Putra ${ }^{1}{ }^{1}$ ghifarigp@gmail.com)

Kharisma Nasionalita ${ }^{2}$

${ }^{2}$ nasionalita.kharisma@gmail.com

$71-87$

Telepon Selular dan Ruang Publik : Representasi Identitas Siswantini

yjuliman@gmail.com

$88-94$

Kepemilikan dan Bingkai Media (Analisis Framing Pemberitaan Joko Widodo Sebagai Kandidat Calon Presiden pada Koran SINDO)

Nani Kurniasaril (nani.kurniasari@kalbis.ac.id ${ }^{1}$ )

Gilang GustiAji² (gilangaji@unesa.ac.id²)

$96-116$ 


\title{
REFLEKSI CITRA INDONESIA SEBAGAI DAMPAK POLITIK MIGRASI TKI KE MALAYSIA
}

\author{
Oleh : \\ Mutia Rahmi Pratiwi, Amida Yusriana \\ Universitas Dian Nuswantoro \\ (mutiarahmipratiwi@gmail.com, amidayusriana88@gmail.com)
}

\begin{abstract}
Abstrak
Indonesia and Malaysia have a very unique relationship. It is depicted by their close position to each other, cooperation, cultural polemic and even employement matter can be main sensitivity factor. Since 2009 until now, abusive and murder cases that involves TKI (Indonesian Foreign Worker) who works in Malaysia are plentiful. This problem is caused by The Indonesia's Migration Politic. This migration is one of the ways to move the suburb worker to the industrial urban work. This kind of internal migration is also work for external condition. The Migration Politic is inherited from Hindia Belanda Government for 46 years. Based on the data, Malaysia has imported the TKI especially domestic worker the most compare to other countries.

This condition affected Indonesia's image in Malaysia. Image building is the depiction of a country in visualization context. There were 2 advertisement in 2012 and 2015 that humiliate Indonesia. The 2012 advertisement showed a big sale for them who hire Indonesian maid while the 2015 advertisement asked Malaysian to hire their Indonesian maid. By these two advertisements, researchers aim to reflect Indonesian image as the effect of The Migration Politic of Indonesian Foreign Worker to Malaysia.
\end{abstract}

Keywords: Image, The Migration Politic, Indonesia, Malaysia, Indonesia, TKI

\begin{abstract}
Abstrak
Indonesia dan Malaysia, dua negara yang memiliki hubungan unik yang terlihat dari letaknya yang berdekatan, hubungan kerjasama yang dilakukan bahkan hingga polemik dari sisi kebudayaan hingga ketenagakerjaan yang menimbulkan sensitifitas bagi kedua negara ini. Dari tahun 2009 hingga saat ini masih banyak kasus pelecehan hingga pembunuhan sadis para TKI (tenaga kerja Indonesia) yang bekerja di Malaysia. Hal ini merupakan salah satu dampak dari politik Migrasi TKI Ke Malaysia. Migrasi sendiri merupakan penyaluran tenaga kerja di daerah ke sektor industri modern di kota yang daya serapnya tinggi. Konsep migrasi internal ini juga berlaku secara eksternal yaitu pengiriman tenaga kerja ke luar negeri. Berdasarkan data yang diperoleh, Malaysia merupakan negara penerima TKI sektor informal terbesar dibandingkan dengan negara-negara lainnya.

Pencitraan merupakan gambaran yang mewakili suatu negara dalam bentuk visualisasi, termasuk iklan. Terdapat dua iklan yang berisi tentang TKI dan jelas "menginjak" harga diri bangsa Indonesia di tahun 2012 dan 2015. Iklan pada tahun 2012 berisi tentang diskon besarbesaran bagi mereka yang mau mempekerjakan TKI dan iklan pada tahun 2015 berisi permintaan bagi para majikan untuk memecat TKI dirumah mereka. Dari dua iklan yang muncul ini, maka penulis akan melakukan kajian teoritis yang menelaah mengenai refleksi citra Indonesia sebagai dampak dari politik migrasi TKI ke Malaysia.
\end{abstract}

Kata Kunci: Refleksi Citra, Politik Migrasi, Indonesia, Malaysia, TKI 


\section{Pendahuluan}

\section{Hubungan Indonesia-Malaysia}

Indonesia dan Malaysia merupakan dua negara yang seringkali disebut dengan negara serumpun, negara tetangga, dan sebagainya. Dari segi letaknya secara geografis, Malaysia dan Indonesia terpisahkan oleh batas laut dan darat. Batas darat antara lain di wilayah Pulau Kalimantan dan batas laut antara lain Selat Malaka, Laut Selebes dan Laut Cina Selatan. Karena wilayahnya yang dekat, maka Indonesia dan Malaysia secara resmi menjalin hubungan diplomatik sejak 31 Agustus 1957 saat Malaysia menyatakan kemerdekaannya.

Hubungan kedua bangsa sebenarnya telah terjalin erat sebelum masingmasing negara merdeka. Itulah sebabnya hingga kini dapat ditelusuri berbagai keturunan dari Indonesia yang tinggal di Semenanjung Malaysia, seperti keturunan Jawa yang berdiam di Pantai Batar Johor, Selangor dan Perak; Keturunan Bugis yang tersebar di Pantai Timur Johor, Pahang dan Terengganu; serta keturunan Aceh yang berdiam di sekitar Pulau Pinang, Kedah dan Perak.

Pada masa awal hubungan bilateral, kedua negara sempat mengalami masa konfrontasi pada tahun 1963-1965. Pemimpin Indonesia dan Malaysia mengambil sikap bijak untuk memulihkan hubungan dan menjadi pelopor dalam pembentukan organisasi regional ASEAN pada tahun 1967. Indonesia dan Malaysia telah melakukan beberapa kerjasama, diantaranya: Pembentukan Eminent Persons Group (EPG); Pembentukan General Border Committee (GBC) merupakan wadah kerjasama bilateral antara Indonesia dengan Malaysia dalam bidang militerpertahanan; Adanya kegiatan pameran produk Indonesia Indonesia pada tahun 2007 di Kuala Lumpur Convention Centre (KLCC); Investasi Malaysia sebesar 18\% dari total jumlah investasi asing di Indonesia; berbagai kerjasama lainnya termasuk pengiriman TKI (Tenaga Kerja Indonesia) ke Malaysia. (Kementrian Luar Negeri Republik Indonesia, 2015, Profil Negara dan Kerjasama, http://www.kemlu.go.id/ penang/Pages/CountryProfile.aspx?1=id, diakses pada tanggal 10 Maret 2016)

Tidak hanya cerita mengenai kerjasama yang menghubungkan antara Indonesia dan Malaysia. Namun persoalanpersoalan seriuspun juga menjadi cerita tak berkesudahan antara Indonesia dan Malaysia. Contoh persoalan yang menghiasi cerita Indonesia Malaysia adalah: terjadinya sengketa Pulau SiPadan dan Ligitan yang berawal di tahun 1960 dan terselesaikan di tahun 2002; Malaysia mengklaim lagu "Rasa sayange" yang berasal dari Maluku dan digunakan untuk promosi kepariwisataan Malaysia pada tahun 2007; Malaysia mengklaim kesenian tarian Reog Ponorogo di tahun 2007. Hubungan antara Indonesia dan Malaysia layaknya saudara dekat, saling membutuhan namun di sisi lain kompleks dengan persoalan-persoalan dalam berbagai aspek.

\section{Politik Migrasi Tenaga Kerja Indonesia}

Fenomena migrasi sangat mewarnai di beberapa negara berkembang, termasuk di Indonesia. Migrasi ini akan menyalurkan surplus tenaga kerja di daerah-daerah ke sektor industri modern di kota-kota yang daya serapnya lebih tinggi, walaupun pada kenyataannya arus perpindahan tenaga kerja dari daerah pedesaan ke perkotaan tersebut telah melampaui tingkat penciptaan lapangan kerja, sehingga migrasi yang terjadi jauh melampaui daya serap sektor industri dan jasa di daerah perkotaan (Todaro, 1998).

Konsep migrasi internal tersebut juga berlaku secara eksternal, yakni pengiriman tenaga kerja ke luar negeri. Kebijakan politik migrasi ini merupakan warisan sejak zaman Pemerintahan Hindia Belanda. Pada masa sebelum kemerdekaan Indonesia, migrasi tenaga kerja Indonesia (TKI) ke luar negeri dilakukan oleh pemer- 
intah Hindia Belanda melalui penempatan buruh kontrak ke negara Suriname, Amerika Selatan, yang juga merupakan wilayah koloni Belanda. Bahan yang diperoleh dari Direktorat Sosialisasi dan Kelembagaan Penempatan Badan Nasional Penempatan dan Perlindungan TKI (BNP2TKI) menyebutkan, sejak 1890 pemerintah Belanda mulai mengirim sejumlah besar kuli kontrak asal Jawa bahkan Madura, Sunda, dan Batak untuk dipekerjakan di perkebunan di Suriname. Tujuannya untuk mengganti tugas para budak asal Afrika yang telah dibebaskan pada 1 Juli 1863 sebagai wujud pelaksanaan politik penghapusan perbudakan sehingga para budak tersebut beralih profesi serta bebas memilih lapangan kerja yang dikehendaki. Dampak pembebasan para budak itu membuat perkebunan di Suriname terlantar dan mengakibatkan perekonomian Suriname yang bergantung dari hasil perkebunan turun drastis. Adapun dasar pemerintah Belanda memilih TKI asal Jawa adalah rendahnya tingkat perekonomian penduduk pribumi (Jawa) akibat meletusnya Gunung Merapi dan padatnya penduduk di Pulau Jawa.

Gelombang pertama pengiriman TKI oleh Belanda diberangkatkan dari Batavia (Jakarta) pada 21 Mei 1890 dengan Kapal SS Koningin Emma. Pelayaran jarak jauh ini singgah di negeri Belanda dan tiba di Suriname pada 9 Agustus 1890. Jumlah TKI gelombang pertama sebanyak 94 orang terdiri 61 pria dewasa, 31 wanita, dan 2 anak-anak. Kegiatan pengiriman TKI ke Suriname yang sudah berjalan sejak 1890 sampai 1939 mencapai 32.986 orang, dengan menggunakan 77 kapal laut.

Penempatan TKI yang didasarkan pada kebijakan pemerintah Indonesia baru terjadi pada 1970 yang dilaksanakan oleh Departemen Tenaga Kerja, Transmigrasi, dan Koperasi dengan dikeluarkannya Peraturan Pemerintah No 4/1970 melalui Program Antarkerja Antardaerah (AKAD) dan Antarkerja Antarnegara (AKAN), dan sejak itu pula penempatan TKI ke luar neg- eri melibatkan pihak swasta (perusahaan pengerah jasa TKI atau pelaksana penempatan TKI swasta). Program AKAN ditangani oleh pejabat kepala seksi setingkat eselon IV dan bertanggung jawab langsung kepada Direktorat Jenderal Pembinaan dan Penggunaan (Sejarah Penempatan TKI Hingga BNP2TKI, 2011, Sejarah Penempatan TKI Hingga BNP2TKI, http://www. bnp2tki.go.id/frame/9003/Sejarah-Penempatan-TKI-Hingga-BNP2TKI, diakses pada tanggal 28 April 2016)

Jika dihitung sejak awal munculnya kebijakan politik migrasi pada tahun 1970 , maka pengiriman TKI hingga saat ini telah berlangsung selama 46 tahun. Dimana sektor informal masih menjadi sumber utama pengiriman tenaga kerja manusia tersebut. Berikut adalah grafik 20 jabatan terbesar profesi tenaga kerja Indonesia di berbagai negara:

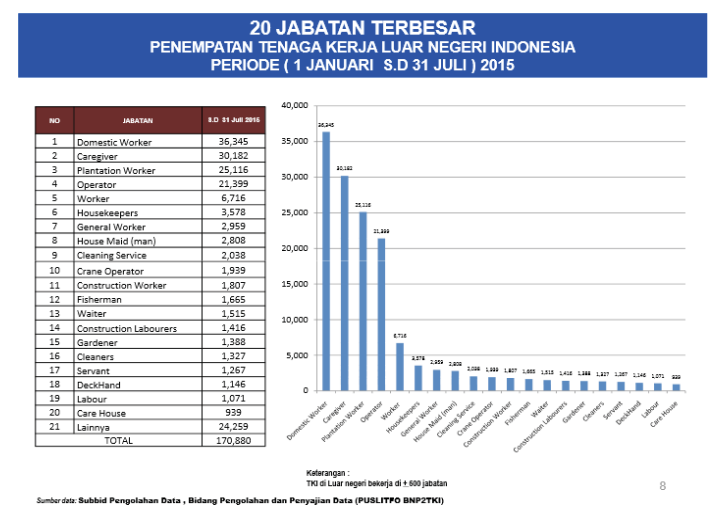

\section{Grafik 1. Jabatan Terbesar Tenaga Kerja Luar Negeri \\ Sumber: http://www.bnp2tki.go.id}

Berdasarkan grafik tersebut, maka sektor domestic worker atau pembantu rumah tangga memegang peranan tertinggi mencapai angka 36.345 jiwa. Sedangkan pekerjaan tenaga ahli belum masuk ke dalam jumlah 20 terbesar. 


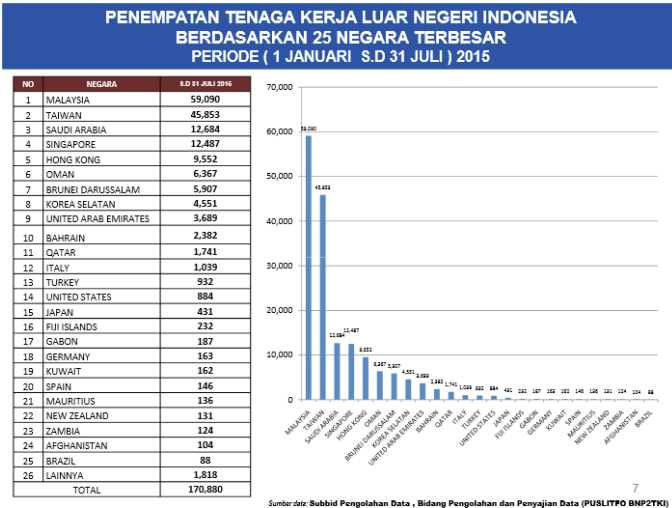

Grafik 2. Grafik Penempatan TKI di 25 Negara Terbesar

Sumber: http://www.bnp2tki.go.id

Grafik di atas menunjukkan Malaysia tetap menjadi negara terbesar dalam hal persebaran tenaga kerja di negara Asing dengan jumlah mencapai hampir 60.000 jiwa hanya berbeda 13.507 jiwa dengan Taiwan yang berada di urutan kedua. Jarak geografi yang dekat dan murahnya kehidupan adalah faktor pertama mengapa TKI lebih banyak bekerja di Malaysia. (Wiji Nurhayat, 2012, Tenaga Kerja Indonesia Paling Banyak Tersebar di Malaysia, http://finance.detik.com/read/2012/09/26 /170223/2038424/4/tenaga-kerja-indonesiapaling-banyak-tersebar-di-malaysia, diakses pada tanggal 1 Maret 2016).

\section{Pembahasan}

\section{Kasus TKI di Malaysia}

Akibat dari banyaknya jumlah TKI di negeri asing sebagai pembantu maka perlu dilakukan kajian yang merefleksi citra indonesia sebagai dampak politik migrasi TKI ke Malaysia. Indonesia cenderung diidentikan sebagai negara asal pembantu rumah tangga dibandingkan negara lainnya yang lebih banyak menguasai bidang tenaga ahli. Mengirimkan tenaga buruh ke negara lain seringkali menimbulkan konsekuensi-konsekuensi serius. Rendahnya tingkat pendidikan tenaga buruh menyebabkan ragam kasus yang berkisar pada wilayah kekerasan yang bersifat domestik. Banyaknya jumlah TKI yang dikirim ke Malaysia tidak hanya merubah tingkat kesejahteraan para TKI namun juga membawa kisah pilu berkaitan banyaknya kasus penganiayaan hingga pembunuhan sadis dan penjualan organ tubuh manusia.

Salah satu kasus serius tersebut terjadi pada tanggal 7 Juni 2009, kasus penganiayaan menimpa TKI bernama Siti Hajar (wanita berusia 33 tahun) disiksa majikannya di Malaysia, Michele. Dalam proses pengadilan di negeri jiran itu Michele terbukti menyiram Siti dengan air panas, menyiksa dengan martil dan gunting hingga menyebabkan cacat permanen pada tubuh Siti. Michele pun divonis penjara selama 8 tahun.

Lalu pada tahun 2010, seorang TKI bernama Nurul Aidah ditemukan tewas dalam bagasi mobil majikannya. Dari hasil otopsi ditemukan lebam-lebam pada tubuh pembantu asal Bogak, Kabupate Batubara, Sumatera Utara itu, akibat pukulan benda tumpul, sehingga kematian Nurul diduga akibat kekerasan majikan. Kembali ditemukan pada bulan Spetember 2010, TKI asal Lampung, Winfaidah yang disiksa dengan disiram air panas, disetrika tubuhnya dan diperkosa berulang kali oleh majikannya.

Kemudian pada tahun 2012 tiga tenaga kerja Indonesia (TKI) asal Nusa Tenggara Barat (NTB) yang bekerja di Malaysia diduga menjadi korban perdagangan organ tubuh di negeri jiran Malaysia. Bahkan ada indikasi penembakan terhadap mereka, meski polisi Malaysia berdalih penembakan itu sebagai upaya membela diri. Kejadian tidak mengenakan yang menimpa para TKI di Malaysia ini bukan kali pertama. Para TKI di negeri Jiran itu sebelumnya seakan kenyang menerima perlakuan diskriminasi dan penyiksaan dari majikan (Mardani, 2012, Potret Kelam TKI di Malaysia, http://www.merdeka. com/peristiwa/potret-kelam-tki-di-malaysia.html, diakses pada tanggal 07 maret 2016).

Setiap tahun jumlah kekerasan dan kematian Tenaga Kerja Wanita di luarneg- 
eri semakin meningkat. Pada tahun 2009, jumlah tenaga kerja yang terkena kasus kekerasan mencapai angka 5.314. Di urutan pertama adalah kekerasan yang dialami TKW di negara Malaysia sebesar 1.748. Posisi kedua, Arab Saudi sebesar 1.048, dan posisi ketiga Yordania sebesar 1.004. Sementara itu, untuk kasus kematian mencapai 1.018 orang, negara yang paling besar dengan jumlah TKW meninggal adalah Malaysia mencapai 687, sedangkan peringkat yang kedua Arab Saudi dengan angka kematian 221, dan yang menduduki urutan ketiga adalah Hongkong dengan junmlah 32 orang. Sedangkan tahun 2010 untuk kasus kematian mencapai angka 1.075 orang (Anhar Rizki, 2011, Tiap Tahun Kekerasan Terhadap Tkw Meningkat, http://nasional. news.viva.co.id/news/read/229833-tiaptahun--kekerasan-terhadap-tkw-meningkat, diakses pada tanggal 04 April 2016).

Banyaknya kasus-kasus penyiksaan tersebut ternyata tidak juga mengubah haluan praktik politik migrasi Pemerintah Indonesia. Indonesia masih terus mengirimkan tenaga buruh ke negara-negara tetangga. Berbagai solusi minor telah diupayakan pemerintah untuk menanggulangi persoalan kekerasan dan ketidaklayakan perlakuan terhadap TKI Indonesia. Penyelesaian minor tersebut ditunjukkan dari kebijakan pemberian handphone bagi para TKI yang akan berangkat bekerja. Tujuannya agar para pekerja dapat segera melaporkan kepada pihak Pemerintah Indonesia jika muncul indikasi kekerasan. Ketidakseriusan pemerintah dalam menggodok solusi yang matang semakin tidak menguntungkan citra Indonesia di mata negara tetangga yang mengkonsumsi jasa buruh Indonesia.

\section{Citra Indonesia di Malaysia}

Masalah citra ini bukanlah persoalan baru. Setiap kali mucul kasus antara Indonesia-Malaysia, media selalu membangun wacana citra Indonesia sebagai bangsa pembantu. Hingga kemudian pada tahun 2015 muncul sebuah iklan produk robot pembersih dengan tulisan 'Fire Your Indonesian Maid NOW!'.

Iklan tersebut terpasang di jalanan Kuala Lumpur. Iklan tersebut dikeluarkan oleh Robovac Malaysia, perusahaan distributor pembersih merek ternama, seperti Neato Robotic asal California, iRobot asal Delaware Amerika Serikat dan LG asal Korea Selatan. Robovac Malaysia mengklaim perusahaannya sebagai "Leading Robotic Vacums Specialist in Malaysia" (Anggi Kusumadewi, 2015, Iklan-Iklan Malaysia yang Menyinggung Pekerja Indonesia, http://www.cnnindonesia.com/ nasional/20150204140501-20-29601/

iklan-iklan-malaysia-yang-menyinggungpekerja-indonesia/, diakses pada tanggal 03 April 2016).

Perusahaan iRobot didirikan sejak 1990olehparaahli robot lulusan Massachusetts Institute of Technology, yakni Colin Angle, Helen Greiner, dan Rodney Brooks. Mereka membuat robot untuk segala macam sektor, namun yang paling diandalkan adalah robot asisten rumah tangga. iRobot mengklaim telah menjual lebih dari 10 juta unit robot asisten rumah tangga. Yang menjadi andalan adalah iRobot Roomba, sebuah penyedot debu yang bisa bergerak otomatis untuk membersihkan rumah dan setiap sudutnya. Dalam profil perusahaan disebutkan jika visi iRobot adalah membuat robot praktis dalam dunia nyata. Perusahaan yang berbasis di Bedford, Massachusets, ini memiliki cabang di lebih dari 60 negara di dunia (Siti Sarifah, 2015, Mengenal Perusahaan iRobot yang Menghina Indonesia, http://teknologi.news.viva. co.id/news/read/585756-mengenal-perusahaan-irobot-yang-menghina-indonesia, diakses pada tanggal 05 April 2016).

Pada tanggal 3 Februari 2015, Fairuz ND seorang warga negara Indonesia berinisiatif mencoba mengirim email kepada CEO iRobot Colin Angle. Dia ingin tahu alasan perusahaan itu memasang iklan yang dianggapnya rasis di Malaysia. 
Fairuz memprotes mengenai keberadaan iklan tersebut dan meminta Colin untuk menindak lanjutinya. Email kemudian dibales oleh Corporate Communications Manager iRobot, Charlie Vaida, yang menjelaskan bahwa iRobot tidak ikut campur dalam pembuatan iklan RoboVac di pasar Malaysia tersebut. Pihak iRobot juga menyebut bahwa iklan itu dibikin oleh dealer yang tidak jelas dan tidak ada hubungannya dengan perusahaan iRobot. "iRobot is not involved in any way in the creation of RoboVac's advertisement in the Malaysia market. It was created by an unauthorized dealer, RoboVac Malaysia, and iRobot is strongly opposed to the content. iRobot is taking this issue very seriously and investigating to understand how and why RoboVac Malaysia mis-used our logo without permission in their inappropriate advertisement," tulis Charlie Vaida dalam email balasan kepada Fairuz ND yang dikutip, Jumat (6/2/2015) (Dha/Ndr, 2015, Perusahaan AS iRobot Mengaku Tak Ada Hubungan dengan Iklan "Pecat TKI" di Malaysia, http://news.detik.com/berita/2825396/perusahaan-as-irobot-mengaku-tak-ada-hubungan-dengan-iklan-pecat-tki-di-malaysia, diakses pada tanggal 05 April 2016).

Iklan rasis terhadap TKI bukan merupakan kali ini saja muncul di Malaysia. Pada tahun 2012, terdapat iklan "Indonesian maids now on SALE. Fast and easy Application. Now your housework and cooking come easy. You can rest and relax. Deposit only RM 3,500! Price RM 7,500 nett". Iklan ini menawarkan diskon 40 persen bagi mereka yang mengambil pembantu rumah tangga asal Indonesia. Iklan ini dicetak dalam bentuk lembaran dan ditempel di berbagai lokasi serta diiklankan di media cetak Malaysia. Iklan ini seolah menganggap bahwa TKI tak ubahnya diperdagangkan seperti barang, bahkan dapat dikatakan sebagai perdagangan manusia. Dan kini terulang lagi, TKI dianggap seperti barang (vacuum cleaner) (Anggi Kusumadewi, 2015, Iklan-Iklan
Malaysia yang Menyinggung Pekerja Indonesia, http://www.cnnindonesia.com/ nasional/20150204140501-20-29601/ iklan-iklan-malaysia-yang-menyinggungpekerja-indonesia/, diakses pada tanggal 03 April 2016).

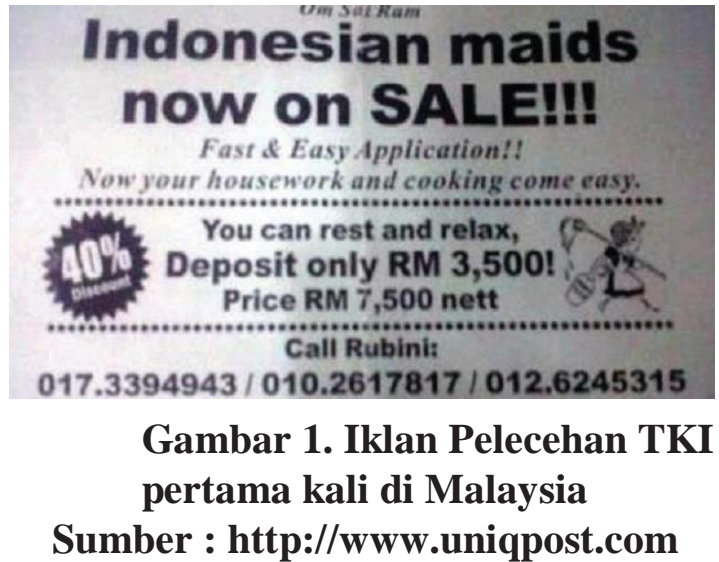

Saat melintas di kawasan Chow Kit, Kuala Lumpur Malaysia, Direktur Eksekutif Migrant Care, Anis Hidayah menemukan selebaran promosi yang berbunyi:"Indonesian maids now on Sale. Fast and Easy application. Now your housework and cooking come easy. You can rest and relax. Deposit only RM 3,500 price $R M$ 7,500 nett." Iklan ini ternyata juga dimuat di media lokal Malaysia. Anis pun menghubungi nomor yang tertera pada selebaran tersebut dan pihak pengiklan yang tidak mengenal Anis pun memberikan banyak informasi seputar promo di selebaran tersebut. Anis mengabarkan hal ini ke berbagai pihak terkait di Indonesia, termasuk media massa dan mendesak pemerintah untuk bertindak tegas menanggai iklan tersebut dan melayangkan protes resmi ke pemerintah Malaysia. Namun respon KBRI sangat lambat karena mereka sudah mengetahui iklan ini sejak seminggu lalu.

Pemerintah belum lagi bersikap, politisi DPR sudah mendahuluinya. Mereka ramai-ramai mengecam promosi PRT Indonesia di Malaysia itu. Anggota Komisi IX Bidang Tenaga Kerja DPR dari Fraksi Golkar, Poempida Hidayatulloh, 
menyatakan iklan "TKI On Sale" sungguh melecehkan Tenaga Kerja Indonesia Penata Laksana Rumah Tangga (TKI PLRT) di Malaysia, sudah mengarah kepada perbudakan modern dan berlawanan dengan penegakan hak asasi manusia. Kolega Poempida di Komisi IX DPR, Rieke Diah Pitaloka, bahkan sudah melontarkan protes resmi ke pemerintah Malaysia. Kepala Badan Nasional Penempatan dan Perlindungan Tenaga Kerja Indonesia (BNP2T$\mathrm{KI}$ ), Jumhur Hidayat mengusulkan pengiriman TKI PLRT dihentikan selamanya apabila pemerintah Malaysia tidak mengambil tindakan tegas terhadap agensi pemasang iklan tersebut (Anggi Kusuma Dewi, Kasus Iklan “TKI On Sale”, Ini Janji Pemerintah Malaysia, 2012, http://fokus.news. viva.co.id/news/read/363153-kasus-iklantki-on-sale-ini-janji-pemerintah-malaysia, diakses pada tanggal 12 Mei 2016)

Munculnya iklan-iklan tersebut dapat menjadi sebuah konstruksi sosial akan citra Indonesia di Malaysia. Istilah konstruksi sosial atas realitas menjadi terkenal sejak diperkenalkan oleh Peter L. Berger dan Thomas Luckmann melalui bukunnya yang berjudul "The Social Construction of Reality, a Treatise in the Sociologycal of Knowledge" (1966). Ia menggambarkan proses sosial melalui tindakan dan interaksinya, yang mana individu menciptakan secara terus menerus suatu realitas yang dimiliki dan dialami bersama secara subjektif.

Berger dan Luckmann (1990:1) memulai penjelasan realitas sosial dengan memisahkan pemahaman "kenyataan" dan "pengetahuan". Realitas diartikan sebagai kualitas yang terdapat di dalam realitasrealitas, yang diakui memiliki keberadaan (being) yang tidak tergantung pada kehendak kita sendiri. Pengetahuan didefinisikan sebagai kepastian bahwa reaitas-realitas itu nyata dan memiliki karakteristik yang spesifik (Bungin, 2006: 193).

Berger dan Luckmann (1990:61) mengatakan, institusi masyarakat tercipta dan dipertahankan atau diubah melalui tindakan dan interaksi manusia. Meskipun masyarakat dan institusi sosial terlihat nyata secara objektif, namun pada kenyataannya semuanya dibangun dalam definisi subjektif melalui proses interaksi. Pada tingkat generalitas yang paling tinggi, manusia menciptakan dunia dalam makna simbolis yang universal, yaitu pandangan hidupnya yang menyeluruh, yang memberikan legitimasi dan mengatur bentuk-bentuk sosial serta memberikan makna pada berbagai bidang kehidupannya. Terjadi dialektika antara individu menciptakan masyarakat dan masyarakat menciptakan individu. Proses dialektika ini terjadi melalui eksternalisasi, objektivasi dan internalisasi.

Institusi yang ada di masyarakat tercipta dan dipertahankan atau diubah melalui tindakan dan interaksi manusia. Khalayak sebagai individu sebelumnya telah memiliki pengalaman atau pengetahuan mengenai tenaga kerja termasuk yang berasal dari Indonesia. Hal ini juga diperkuat dengan pengetahuan yang mereka dapatkan dari media termasuk iklan IRobot yang sempat terpasang iklannya di Malaysia. Pengalaman dan pengetahuan itu kemudian menjadi dasar khalayak untuk memahami status sosial TKI (Tenaga Kerja Indonesia) dan bangsa Indonesia di Malaysia sehingga terbentuklah konstruksi bahwa Indonesia = Bangsa Pembantu dan Pembantu $=$ Indonesia. Jika individu lainnya memiliki bentuk konstruksi yang sama dari iklan ini maka konstruksi yang bersifat subjektif akan berubah menjadi objektif. Hal ini terjadi karena adanya penegasan berulang-ulang yang diberikan oleh individu lain yang juga memiliki definisi subjektif yang sama.

\section{Menurut Berger Harckmann} (1990:xx, Nugroho 1999: 123), realitas sosial adalah pengetahuan yang bersifat keseharian yang hidup berkembang di masyarakat, seperti: konsep, kesadaran umum, wacana publik, sebagai hasil dari konstruksi sosial. 
Realitas sosial dikunstruksi melalui proses eksternalisasi, objektivasi, daninternalisasi. Konstruksi sosial tidak berlangsung dalam ruang hampa, namun sarat dengan kepentingan-kepentingan.

Realitas sosial terdiri dari realitas objektif, realitas simbolis dan realitas subjektif. Realitas objektif adalah realitas yang terbentuk dari pengalaman di dunia objektif yang berada di luar diri individu, dan realitas ini dianggap kenyataan. Realitas simbolis merupakan ekspresi simbolis dari realitas objektif dalam berbagai bentuk. Realitas subjektif adalah realitas yang terbentuk sebagai proses penyerapan kembali realitas objektif dan simbolis ke dalam individu melalui proses internalisasi (Subiakto, 1997: 93 dalan Bungin, 2006: 196).

Eksternalisasi adalah bagian penting dalam kehidupan individu dan terjadi pada tahap yang sangat mendasar, dalam satu pola perilaku interaksi antara individu dengan produk-produk sosial masyarakatnya. Ketika sebuah produk sosial telah menjadi bagian penting dari masyarakat yang setiap saat dibutuhkan oleh individu, maka produk sosial itu menjadi bagian penting dalam kehidupan seseorang untuk melihat dunia luar. Dengan demikian, tahap eksternalisasi ini berlangsung ketika produk sosial tercipta di masyarakat, kemudian individu mengeksternalisasikan (penyesuaian diri) ke dalam dunia sosikulturalnya sebagai bagian dari produk manusia.

Tahap objektivasi produk sosial terjadi dalam dunia intersubjektif masyarakat yang dilembagakan. Individu memanifetasikan diri dalam produk-produk kegiatan manusia yang tersedia, baik bagi produsen-produsennya, maupun bagi orang lain sebagai unsur dari dunia bersama. Objektivasi bertahan lama sampai melampaui batas tatap muka dimana mereka dapat diapahami secara langsung. Objektivasi bisa terjadi melalui penyebaran opini sebuah produk sosial yang berkembang di masyarakat melalui diskursus opini masyara- kat tentang produk sosial, dan tanpa harus terjadi tatap muka antar individu dan pencipta produk sosial itu. Hal yang terpenting dalam objektivasi adalah pembuatan signifikansi, yakni pembuatan tanda-tanda oleh manusia. Tanda dapat dibedakan dari objektivasi-objektivasi lainnya, karena tujuannya yang eksplisit untuk digunakan sebagai isyarat atau indeks bagi pemaknaan subjektif maka objektivasi juga dapat digunakan sebagai tanda, meskipun semula tidak dibuat untuk maksud itu.

Internalisasi dalam arti umum merupakan dasar bagi pemahaman mengenai "sesama saya", yaitu pemahaman individu dan orang lain serta pemahaman mengenai dunia sebagai sesuatu yang maknawi dari kenyataan sosial. Pemahaman ini bukanlah merupakan hasil dari penciptaan makna secara otonom oleh individu-individu yang terisolasi, melainkan dimulai dengan individu yang "mengambil alih" dunia dimana sudah ada orang lain. Dalam proses "mengambil alih" dunia, individu dapat memodifikasi dunia tersebut bahkan dapat menciptakan kembali dunia secara kreatif. Bagaimanapun jungam bentuk internalisasi yang kompleks, individu tidak hanya memahami proses-proses subjektif orang lain yang berlangsung sesaat. Individu memahami dunia dimana ia hidup dan dunia itu menjadi dunia individu bagi dirinya (Bungin, 2006: 202).

Jika menelaah iklan irobot tersebut dengan menggunakan semiotika maka akan dapat diperoleh banyak unsur-unsur yang menguatkan bagaimana citra Indonesia.

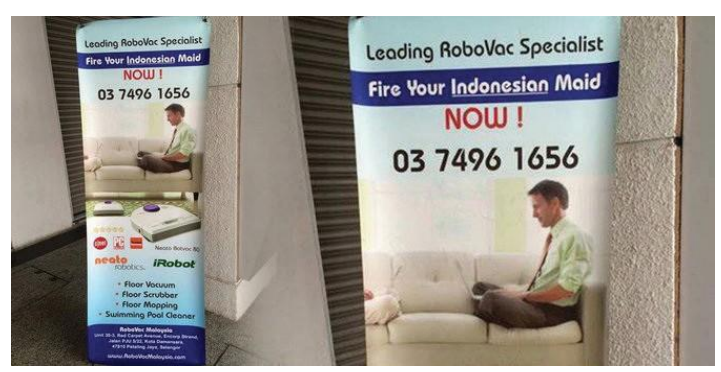

Gambar 2. Standing Banner Iklan iRobot

Di gambar iklan terlihat seorang pria Caucasian tengah duduk bersila 
diatas sebuah sofa berwarna putih sambil mengetik di atas laptop miliknya. Di bawah lantainya, terlihat Irobot berbentuk kotak pipih berwarna putih yang sedang bekerja untuk membersihkan sebuah karpet bulu. Dengan menggunakan metode semiotika milik Saussure, maka yang pertama dilakukan adalah menentukan signifier, kemudian dari signifier tersebut akan ditentukan yang menjadi signified-nya.

Berdasarkan gambar iklan tersebut maka akan diperoleh beberapa obyek, antara lain dalam bentuk gambar dan tulisan. Gambar terdiri dari manusia, sebuah sofa, laptop, karpet, robot pembersih dan ruangan berjendela. Sedangkan tulisan terdiri dari sebuah pesan komunikasi yakni Leading Robovac Specialist, Fire Your Indonesian Maid NOW!, 037496 1656, iRobot, Floor Vacuum, Floor Scrubber, Floor Mopping, Swimming Pool Clener, Robovac Malaysia.

Berdasarkan gambar dan tulisan tersebut maka dalam penelitian yang akan diteliti adalah komposisi gambar dan komposisi tulisan. Standing banner tersebut terdiri dari dua komposisi gambar, yaitu: posisi diatas sofa dan posisi di bawah sofa (diatas lantai). Pada komposisi pertama terdapat pria Caucasian dengan tubuh tinggi dan putih dalam posisi duduk di sofa memangku laptop berwarna putih dengan posisi kaki bersila. Pria Caucasian ini menggunakan hem polos berwarna hijau muda, celana kerja berwarna abu-abu dan berdasi. Lengan hem yang digunakan digulung hingga ke siku. Di hadapan lakilaki tersebut terdapat gambar orang lain (cenderung mengarah kepada kaki perempuan) karena menggunakan celana warna krem dengan posisi kaki bersila dan memangku laptop.

Pria Caucasian tersebut terlihat sedang berada di dalam ruangan dengan jendela yang berwarna putih yang menggambarkan cahaya yang masuk sehingga terlihat ruangan yang bersih. Sementara komposisi kedua terdapat alat pember- sih IRobot yang letaknya dibawah, tidak sejajar dengan sofa namun sejajar dengan bagian bawah sofa dan diatas karpet. Gambar alat ini terdapat dua, yaitu dalam ukuran yang lebih kecil dan lebih besar. Gambar alat yang lebih besar memperjelas bagaimana bentuk dari alat pembersih lantai ini. Analisa semiotika akan dilakukan pada kedua komposisi tersebut karena secara tersirat menunjukan makna tertentu berkaitan dengan tenaga kerja Indonesia yang disamakan dengan alat pembersih lantai.

Standing banner tersebut terdiri dari dua komposisi tulisan. Komposisi pertama adalah sekumpulan tulisan headlines yang ada di atas gambar dan yang kedua adalah sekumpulan tulisan yang ada di bawah. Pada tulisan di atas gambar (komposisi pertama) berisi teks yang bersifat menghina Indonesia. Sementara komposisi kedua berupa keterangan kegunaan iRobot dan alamat tempat iRobot dijual. Analisa semiotika akan dilakukan pada komposisi pertama karena kalimat yang digunakan mengandung masalah yang menjadi inti dalam tulisan ini.

Pria Caucasian merupakan kelompok luas masyarakat dari Eropa, Asia Barat dan bagian dari India dan Afrika Utara. Pria yang tampil dalam iklan merupakan pria kulit putih yang mewakili negara asal pembuatan alat IRobot, Amerika. Posisi duduk bersila yang ditunjukan oleh pria dalam gambar iklan ini juga menunjukan makna tertentu.

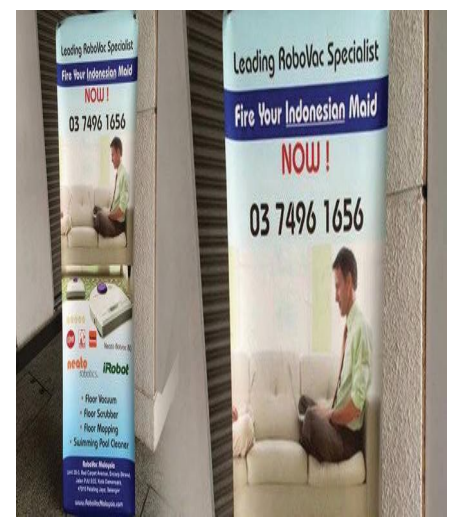

Gambar 3. Potongan Gambar Signifier Gambar Utama 
Menurut Janine Driver, Penulis buku "You Can't Lie to Me" (buku best seller, dinobatkan oleh New York Time's), seseorang yang duduk dengan kaki terbuka lebar menandakan bahwa dia adalah pribadi yang mendominasi dan memiliki kekuasaan yang besar, tidak pernah sungkan untuk menunjukan ke lingkungan sekitar bahwa Anda berkuasa. Karakter orang ini adalah arogan, sombong dan kurang memiliki empati (Mellisa, 2014, Makna Dibalik Kebiasaan Pria Duduk dengan Kaki Terbuka Lebar, http://female. kompas.com/read/2014/06/24/1558030/ Makna.di.Balik.Kebiasaan.Pria.Duduk. dengan.Kaki.Terbuka.Lebar. Diakses pada tanggal 03 Mei 2016).

Jika dikaitkan dengan makna gambarnya, pengiklan berusaha menunjukan bahwa pria yang sedang duduk di sofa merupakan sosok yang berkuasa, arogan, sombong dan kurang memiliki empati. Hal ini menegaskan positioning dari makna gambar yang muncul. Posisi lengan hem yang digulung hingga ke siku menegaskan bahwa pria ini tidak sedang dalam suasana formal atau sedang santai.

Pria dalam iklan iRobot ini menggunakan hem polos berwarna hijau muda, celana kerja berwarna abu-abu dan berdasi. Pakaian yang digunakan menunjukan bahwa ia adalah pria bekerja, modern dan memiliki kemampuan finansial yang mapan. Laptop yang dipangku oleh pria ini berwarna putih dengan desain slim yang semakin menunjang kesan modern. Warna memiliki makna tersendiri dimana makna dapat menceritakan suatu hal, budaya serta pemaknaan positif dan negatif. Termasuk juga warna-warna yang muncul dalam gambar iklan iRobot ini. Warna hijau (hem yang digunakan) berkaitan dengan tanaman, lingkungan alami. Secara positif warna hijau memiliki makna kesuburan, uang, pertumbuhan, penyembuhan/pengobatan, kesuksesan, alam, kesesuaian, kebenaran dan pemuda. Secara negatif warna hijau bermakna keserakahan, iri hati,kemuakan, meracuni, kerusakan, kurang berpengalaman. Dalam budaya asli Amerika, warna hijau terkait dengan kehendak, atau kemauan manusia (Morioka dan Terry, 2006: 28-30). Signified dari signifier warna hijau adalah: (1) secara budaya, ia memiliki kehendak dan berpengalaman; (2) Warna baju yang digunakan melambangkan kesuksesan dan kesesuaian.

Warna abu-abu pada celana berkaitan dengan kenetralan. Secara positif warna abu-abu memiliki makna keseimbangan, keamanan, hal yang dapat diandalkan, kesopanan, kematangan/kedewasaan, kecerdasan dan kebijaksanaan. Secara negatif warna abu-abu memiliki makna kurangnya komitmen, ketidaktentuan, kemurungan, kegelapan, kebosanan, keraguan, dan kesedihan. Dalam budaya asli Amerika, abuabu dikaitkan dengan kehormatan dan persahabatan dan merepresentasikan industri (Morioka dan Terry, 2006: 30-31). Dalam iklan ini, signified dari celana warna abuabu adalah: (1) secara budaya menunjukan kehormatan dan persahabatan; (2)warna abu-abu melambangkan kematangan dan kecerdasan.

Desain ruangan dalam iklan ini memunculkan beberapa benda yang mepresentasikan suatu hal. Dominasi warna ruang adalah putih, furniture yang nampak adalah sofa dan jendela yang terkonsep modern dan minimalis masih dengan sentuhan warna putih (ada kecenderengan ke warna putih tulang). Warna putih berkaitan dengan penerangan dan kemurnian atau kejernihan. Secara positif, warna putih bermakna kesempurnaan, pernikahan, kebersihan, kebaikan, kemurnian, kelembutan, kesucian, kesederhanaan dan kebenaran. Secara negatif, warna putih bermakna kerapuhan dan pengasingan (terisolasi). Di Amerika Utara, Eropa, warna putih menandakan orang yang memiliki warna kulit bercahaya dari keturunan kaukasia (Morioka dan Terry, 2006: 30-31). Dalam iklan ini, signified dari dominasi warna putih dalam ruangan adalah: (1) secara bu- 

Migrasi TKI ke Malaysia

daya menunjukan status yang lebih tinggi karena warna kulit yang putih (bercahaya); (2) warna putih melambangkan kebersihan dan kelembutan.

Posisi alat yang dibawah menunjukkan bahwa ia tidak sejajar dengan sofa namun sejajar dengan bagian bawah sofa dan diatas karpet. Gambar alat ini terdapat dua, yaitu dalam ukuran yang lebih kecil dan lebih besar. Gambar alat yang lebih besar memperjelas bagaimana bentuk dari alat pembersih lantai ini.

Posisi alat pembersih di ruangan yang bersih dengan dukungan desain ruang yang modern dan elegan menunjukan bahwa alat ini letaknya dibawah tidak sejajar dengan sofa dan orang yang digambarkan duduk di sofa. Posisi ini menunjukan bahwa majikan menjadi pihak yang memiliki kekuasaan, kebenaran, terhormat, namun cenderung arogan dan sombong. TKI dianggap sejajar dengan alat kebersihan IRobot yang posisinya tidak lebih tinggi (terhormat) dari majikan (diwakili oleh orang Kaukasian). Batasan gambar yang diteliti hanya sampai pada gambar alat pembersih IRobot saja karena tulisan yang berada dibawah gambar hanya menjelaskan beragam produk yang dijual.

Tulisan terdiri dari Leading RoboVac Specialist, Fire Your Indonesian Maid NOW!. Dalam tulisan Fire Your Indonesian Maid jika dibandingkan dengan tulisan di atasnya yakni Leading RoboVac Specialist terdapat perbedaan bahwa tulisan Fire Your Indonesian Maid ditonjolkan dengan ribbon banner warna biru tua. Warna yang dipilih jauh lebih gelap dibandingkan warna latar dari standing banner yakni biru muda yang juga menjadi latar belakang tulisan Leading RoboVac Specialist. Pada tulisan Leading RoboVac Specialist, warna yang digunakan adalah warna hitam. Warna hitam pada teks dapat mengandung makna kekuasaan, kemewahan, kuat, seksi, ajaib, jahat dan mahal. Jika dikaitkan dengan makna teks yang berusaha menggambarkan pengiklan sebagai pemimpin dalam spesialisasi $R o$ boVac, maka warna hitam berusaha menguatkan kekuasaan dan kekuatan RoboVac Malaysia.

Berdasarkan Jill Morton dalam A Guide To Color Symbolism menyatakan bahwa warna biru merupakan lambang bagi makna - makna berikut: Kerohanian, Kepercayaan, Kebenaran, Kebersihan, Ketenangan, Kepuasan, immaterial, Kepasifan, Pemahaman, Konservatif, Keamanan, Tekhnologi, Maskulinitas, Dingin dan beku, Introversi, Melankolis dan Ketertekanan (Morton, 1997: 27).

Dalam hal ini warna biru pada banner memiliki signified kebersihan karena tema iklan adalah tentang robot pembersih rumah. Selain itu dapat mengandung signified sebagai bentuk upaya membangun kepercayaan pada konsumen karena terdapat kandungan kebenaran dalam warna biru.

Sementara itu pada ribbon banner menunjukkan warna Indigo, arti warna Indigo atau biru tua (biru tengah malam) adalah warna yang kuat terkait dengan sisi kanan otak. Ini bergema dengan cara 'New Age' dalam berpikir. Secara psikologis warna indigo menyampaikan integritas dan ketulusan dalam dan merangsang kreativitas dan intuisi. Walaupun diartikan dalam konteks struktur, ritual tradisi, dan upacara, warna indigo juga dapat mengubah pemikiran dan keyakinan orang dalam mengembangkan wawasan baru dan semangat perintis. Ini menanamkan pesan tanggung jawab yang besar dan citacita yang tinggi. Secara psikologis, indigo membantu memperluas pikiran dan bebas dari ketakutan dan hambatan.

Dalam konteks penelitian ini, maka warna biru tua selain menunjukkan ketajaman dibanding warna di sekitarnya juga dapat memunculkan signified sebagai upaya mengubah pemikiran dan keyakinan orang yang membacanya. Bahwa tulisan dalam ribbon banner tersebut dibuat untuk meyakinkan konsumen, dalam hal ini agar konsumen segera memecat pembantu In- 
donesia mereka.

Tulisan pada Fire Your Indonesian Maid berwarna putih. Untuk atribut seperti cetak tebal dan varian huruf tidak berbeda dengan tulisan sebelumnya yakni Leading Robovac Specialist. Pilihan warna putih dengan latar belakang biru tua menunjukkan signified bahwa tulisan tersebut lebih penting dibanding tulisan sebelumnya yang memiliki latar belakang biru muda sama dengan keseluruhan warna standing banner.

Warna putih mengandung makna kemurnian, kebersihan, kebenaran, tidak berdosa, kesucian, kerohanian, kemewahan, kehalusan, kebaruan, lunak, kesterilan dan kematian (Morton, 1997: 37). Berdasarkan kandungan makna pada signifier warna putih dan biru, terdapat kesamaan bahwa keduanya sama-sama menunjukkan signified kebersihan dan kebenaran. Warna putih dengan latar belakang biru tua berusaha menarik perhatian konsumen dibandingkan pada tulisan lainnya. Warna tersebut selain bermanfaat dalam mempertegas warna juga dapat bermakna memperkuat kesan kalimat. Jika warna latar belakang biru menunjukkan signified kebenaran, maka aspek putih semakin mempertegas kebenaran signified pada tulisan Fire Your Indonesian Maid. Secara optikal, warna putih dapat menghasilkan sorotan (Morton, 1997:37). Warna putih menyorot jauh lebih tajam dibanding komposisi warna di sekitarnya. Yang diperoleh dari signifier putih adalah makna memperkuat makna kebenaran dan menghasilkan kekuatan sorotan.

Aspek signifier yang lain adalah garis bawah pada kata Indonesian. Garis bawah signified nya adalah mempertegas dan menekankan. Maka kata Indonesian yang bermakna orang Indonesia ditekankan sekali dalam pesan ini. Secara komposisi, kata Indonesian diharapkan menjadi kata yang paling menonjol dibanding pesan komunikasi yang lainnya. Pada tulisan NOW! Terdapat signifier warna merah, huruf yang berbeda dibanding tulisan sebelumnya, huruf kapital, ukuran yang lebih besar dan tanda seru. Dari signifier - signifier tersebut dapat dilihat bahwa ada upaya mempertegas.

Signifier warna merah memiliki signified kehangatan, energi, kekuatan, terburu - buru, dinamisme, aktivitas, keberanian, cinta, passion, semangat, dominasi, pelanggaran, perlawanan, perang dan pertempuran, perusakan, seksualitas dan prostitusi. Selain signified tersebut, secara kontemporer warna merah mengandung maknaberhenti. Sedangkan dalam konteks fashion dapat dikenal sebagai pengambil perhatian. Dalam aspek optik sendiri warna merah memberikan kesan bahwa obyek berwarna merah tampak lebih dekat dibanding sebenarnya (Morton, 1997: 23 - 24).

Dengan menyesuaikan dengan pesan untuk memecat pembantu indonesia sekarang juga, signifier NOW! Memiliki signified utuh yakni agar konsumen dapat berhenti sejenak membaca bagian NOW karena memiliki unsur menarik perhatian dan secara keseluruhan mengandung makna semangat, atau menimbulkan aksi untuk melakukan sesuatu segera. Secara keseluruhan komposisi dari tulisan dalam standing banner tersebut memberikan signified bahwa dalam iklan tersebut pesan Fire Your Indonesian Maid NOW! adalah yang paling diutamakan. Ditambahkan dengan pesan Leading RoboVac Specialist yang bermakna bahwa pemilik iklan ini adalah yang paling dapat dipercaya (Leading). Dan tulisan NOW! yang meminta target konsumen segera memecat pembantu Indonesia.

Telaah semiotika pada iklan yang sempat ramai menjadi kontroversi di Indonesia tersebut menjadi salah satu contoh refleksi citra Indonesia sebagai dampak politik migrasi TKI ke Malaysia. Berdasarkan kajian di atas, ditemukan indikator-indikator bagaimana Indonesia dianggap sebagai bangsa yang lebih rendah dibanding Malaysia. 


\section{Penutup}

Simpulan

Dari hasil kajian teoritis yang telah dilakukan penulis dapat disimpulkan bahwa citra Indonesia yang tervisualisasikan dalam dua iklan mengenai TKI Malaysia adalah rendah (karena tenaga kerja disamakan dengan barang) dan tidak lebih baik dari fungsi robot pembersih rumah tangga. Dalam iklan yang muncul di media cetak Malaysia pada tahun 2012, kata-kata yang muncul merupakan kata-kata yang menyudutkan para TKI karena dengan harga murah maka majikan bisa mempekerjakan TKI. Sedangkan dalam iklan yang muncul di tahun 2015 terjadi justifikasi yang dilakukan melalui dua komposisi, yaitu: komposisi gambar dan tulisan. Adanya pemaksaan untuk segera memecat TKI yang sudah bekerja dan menggantikannya dengan robot. Dengan menggunakan analisis semiotika, pada komposisi tulisan penguatan pesan justifikasi dilakukan dengan banyaknya signifier pada tulisan Indonesian dan kata "now". Sedangkan pada komposisi gambar, justifikasi ditunjukan dengan letak IRobot dan visualisasi yang diwakili oleh gesture dan penampilan pria; serta pemilihan warna secara keseluruhan.

\section{Daftar Pustaka}

\section{Buku}

Berger, Arthur A.. (1998). Signs in Contemporary Culture: An Introduction to Semiotics. Wisconsin: Sheffield Publishing Company.

Bungin,Burhan. (2006). Sosiologi Komunikasi : Teori, Paradigma, dan Diskursus Teknologi Komunikasi di Masyarakat. Jakarta: Kencana Prenada Media Group

Morioka, Adam dan Terry Stone. (2006). Color Design Workbook. Amerika: Rockport

Morton, Jill. (1997). A Guide To Color Symbolism. Colorcom Publishing.
Sobur, Alex. (2006). Semiotika Komunikasi. Bandung: Remaja Rosdakarya

Van Zoest, Aart. (1995). Refleksi Atas Semiotik" dalam Jurnal Filsafat, Unas, Jakarta

\section{Internet}

Anhar Rizki, 2011, Tiap Tahun Kekerasan Terhadap Tkw Meningkat, http://nasional. news.viva. co. id/news/read/229833tiap-tahun--kekerasan-terhadap-tkwmeningkat, diakses pada tanggal 04 April 2016

Anggi Kusuma Dewi, 2012, Kasus Iklan "TKI On Sale”, Ini Janji Pemerintah Malaysia, http://fokus.news.viva.co.id/news/ read/363153-kasus-iklan-tki-on-sale-inijanji-pemerintah-malaysia, diakses pada tanggal 12 Mei 2016

Anggi Kusumadewi, 2015, Iklan-Iklan Malaysia yang Menyinggung Pekerja Indonesia, http://www.cnnindonesia.com/ nasional/20150204140501-20-29601/ iklan-iklan-malaysia-yang-menyinggungpekerja-indonesia/, diakses pada tanggal 03 April 2016

Dha/Ndr, 2015, Perusahaan AS iRobot Mengaku Tak Ada Hubungan dengan Iklan "Pecat TKI" di Malaysia, http://news. detik.com/berita/2825396/perusahaan-asirobot-mengaku-tak-ada-hubungan-dengan-iklan-pecat-tki-di-malaysia, diakses pada tanggal 05 April 2016

Kementrian Luar Negeri Republik Indonesia, 2015, Profil Negara dan Kerjasama, http:// www.kemlu.go.id/penang/Pages/CountryProfile.aspx?l=id, diakses pada tanggal 10 Maret 2016

Mardani, 2012, Potret Kelam TKI di Malaysia, http://www.merdeka.com/peristiwa/ potret-kelam-tki-di-malaysia.html, diakses pada tanggal 07 maret 2016

Mellisa, 2014, Makna Dibalik Kebiasaan Pria Duduk dengan Kaki Terbuka Lebar, http://female.kompas.com/ read/2014/06/24/1558030/Makna. 
di.Balik.Kebiasaan.Pria.Duduk.dengan. Wiji Nurhayat, 2012, Tenaga Kerja Indonesia

Kaki.Terbuka.Lebar. Diakses pada tanggal 03 Mei 2016

Sejarah Penempatan TKI Hingga BNP2TKI, 2011, Sejarah Penempatan TKI Hingga BNP2TKI, http://www.bnp2tki.go.id/ frame/9003/Sejarah-Penempatan-TKI-

Hingga-BNP2TKI, diakses pada tanggal 28 April 2016

Siti Sarifah, 2015, Mengenal Perusahaan iRobot yang Menghina Indonesia, http://teknologi.news.viva.co.id/news/ read/585756-mengenal-perusahaan-irobot-yang-menghina-indonesia, diakses pada tanggal 5 April 2016
Paling Banyak Tersebar di Malaysia, http:// finance.detik.com/read/2012/09/26/170 223/2038424/4/tenaga-kerja-indonesiapaling-banyak-tersebar-di-malaysia, diakses pada tanggal 1 Maret 2016

http://www.bnp2tki.go.id

http://www.uniqpost.com 